\title{
Rupestrian Paintings from the Archaeological Area of Piripiri, Piauí, Brazil: A Current Overview
}

\author{
Luis Carlos Duarte Cavalcante* \\ Center of Natural Sciences, Federal University of Piauí (UFPI), Brazil
}

Submission: December 31, 2018; Published: January 11, 2019

*Corresponding author: Luis Carlos Duarte Cavalcante, Center of Natural Sciences, Federal University of Piauí (UFPI), 64049-550 Teresina, Piauí, Brazil

\begin{abstract}
The rural area from the municipality of Piripiri, in the state of Piauí, Northeastern Brazil, is known to contain several archaeological sites, which are essentially sandstone shelters and walls decorated with rupestrian paintings and engravings. Located in the Corrente stream margins, predominantly in the villages known as Buriti dos Cavalos, Cadoz Velho, and Jardim, the rocky monuments present high density of prehistoric inscriptions. The rupestrian paintings mainly represent abstract figures, spear throwers, human handprints, anthropomorphs and zoomorphs, in different hues of red, but also in yellow, black, gray (including greenish-gray), green-olive, white, pink, wine, dark-purple and orangish. Besides the polychromy, the ancient inscriptions exhibit frequent overlaps and recurrences of the motifs represented in the rocky supports. Eight archaeological sites are briefly presented and their main features are described.
\end{abstract}

Keywords: Rupestrian paintings; rupestrian engravings; archaeological heritage; archaeological area of Piripiri; Brazil

\section{Introduction}

The Northeastern Brazil is a region extremely rich in archaeological sites [1,2]. Only in the Serra da Capivara National Park (Southeast Piauí), more than 940 archaeological sites are known [3-5]. The rupestrian paintings of these region were dated by combining different dating techniques on samples from several of those archaeological sites. Data accumulated up to now suggest that some inscriptions have ages estimated from ca. 30,000 years BP [6-9]. Due to their expressive number and the cultural value of these archaeological sites, especially those decorated with an exceptional collection of prehistoric rupestrian paintings, the Serra da Capivara National Park was formally recognized to be a Human Heritage by UNESCO (United Nations Educational, Scientific and Cultural Organization) $[3,10]$. Besides the Serra da Capivara National Park, the Serra das Confusões National Park [4] and the Sete Cidades National Park are particularly rich in archaeological sites.

Archaeological sites from Piripiri
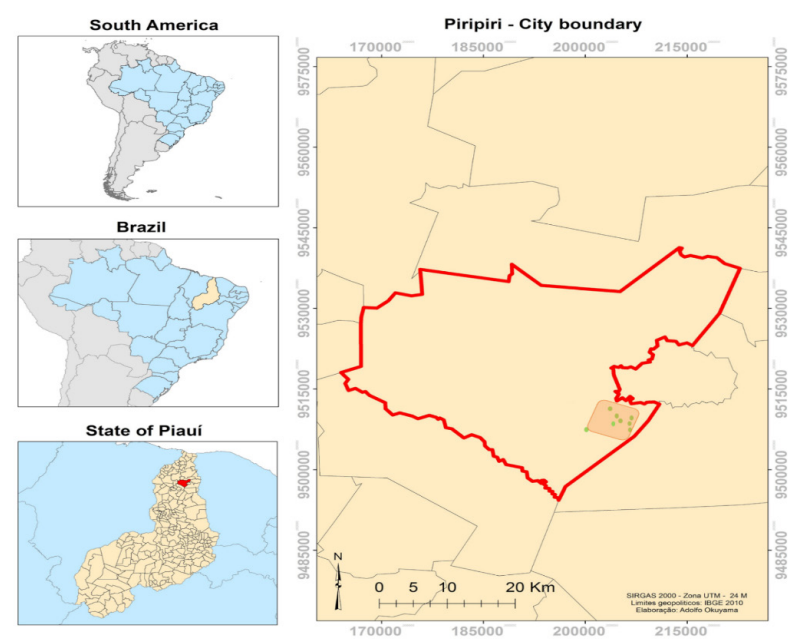

Figure 1: Map of the municipality of Piripiri and detail of the concentration of archaeological sites located in the Corrente stream margins. 


\section{Global Journal of Archaeology \& Anthropology}

The objective of this review article is to present the main characteristics of the prehistoric rupestrian paintings from eight archaeological sites located in the rural area of the municipality of Piripiri (Figure 1), North Piauí, Brazil, which have been investigated since 2009 [11,12].

\section{Pedra do Cantagalo I}

Pedra do Cantagalo I is an archaeological site located in the Jardim village, rural area of the municipality of Piripiri. It consists of a sandstone shelter decorated with more than 1,950 rupestrian paintings representing mainly abstract figures, spear throwers, human handprints and anthropomorphic and zoomorphic motifs, in different hues of red, but also in yellow, black, gray, white, pink, wine, dark-purple and orangish [13,14] (Figure 2). Besides the high density of prehistoric inscriptions and polychromy, this archaeological site also stands out due to the overlaps and recurrences of the figures represented. Rupestrian engravings (some were painted), chipped lithics, polished lithics, ceramic fragments and mineral pigments in the form of red and yellow ochres also were found [13-15] (Figure 3).

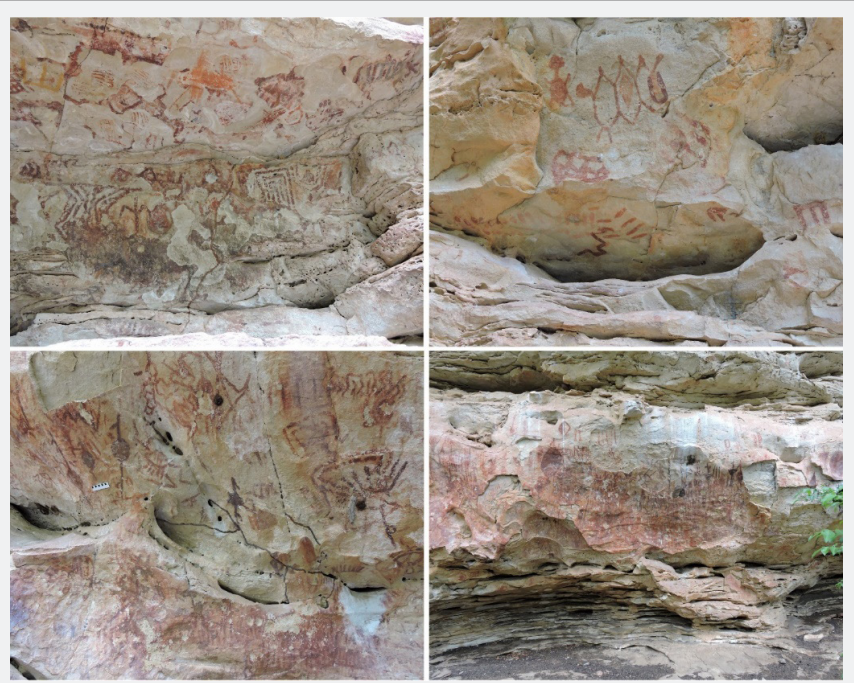

Figure 2: Details of the rupestrian paintings from the Pedra do Cantagalo I.
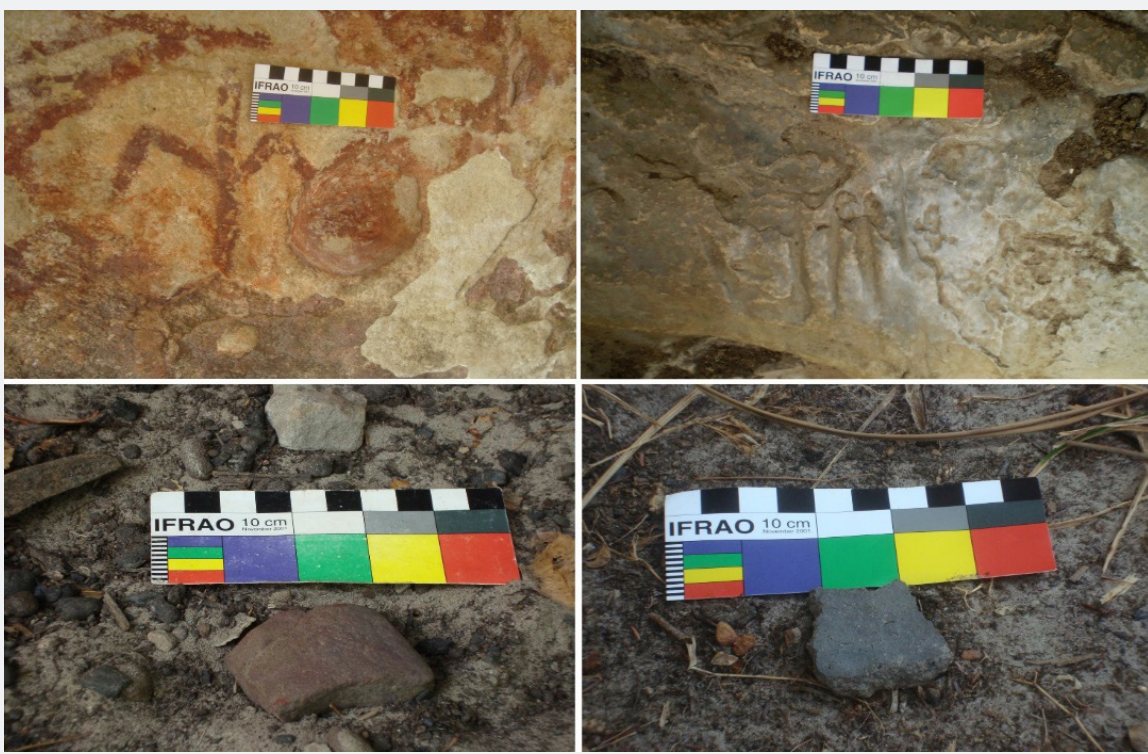

Figure 3: Details of the rupestrian engravings, red ochres and ceramic fragments found in the Pedra do Cantagalo I.

Residual charcoals found in well-structured hearths, as recently evidenced from excavations in this rocky shelter, were ${ }^{14} \mathrm{C}$-dated using accelerator mass spectrometry (AMS) as being from 1,180 \pm 30 years before present (BP; calibrated result at 95\%

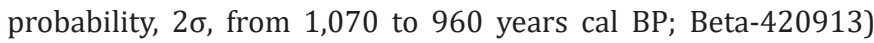
$[16,17]$. Samples containing thin layers of paint from rupestrian paintings of different colors, as well as red and yellow ochres, ceramic fragments, palaeosediments and saline efflorescences samples collected in this archaeological site were investigated by energy dispersive X-ray fluorescence, CHN elemental analysis, scanning electron microscopy, energy dispersive spectroscopy, Fourier transform infrared spectroscopy, ${ }^{57} \mathrm{Fe}-$ Mössbauer spectroscopy, Raman spectroscopy, grazing incidence $\mathrm{X}$-ray diffraction, powder X-ray diffraction and magnetization 


\section{Global Journal of Archaeology \& Anthropology}

measurements using vibrating sample magnetometer, in an effort to assess the chemical and mineralogical characteristics of these materials [14,16-21].

Despite of the several experimental difficulties to analyze these archaeological materials from the cultural heritage, particularly due to the complex chemical and mineralogical composition and to the exceptionally small amount of samples commonly available for manipulation in the laboratory, the chemical and mineralogical data provide stimulating evidences and detailed information about the chemical-mineralogical nature of these vestiges of prehistoric human activity from the rocky shelter Pedra do Cantagalo I.

The archaeometry has been used as an important tool for the analysis of several types of ancient materials of archaeological sites from Piauí and the ${ }^{57} \mathrm{Fe}$ Mössbauer spectroscopy has been used as a non-destructive nuclear technique and decisively fundamental on the chemical-mineralogical characterization of ferruginous species of these materials $[10,14,16,18-34]$.

\section{Pedra do Atlas}

The archaeological site known as Pedra do Atlas is a sandstone shelter located in the Buriti dos Cavalos village, rural area of the municipality of Piripiri, decorated with 423 rupestrian paintings represent abstract figures, spear throwers, human handprints and anthropomorphic and zoomorphic motifs, in different hues of red, yellow, gray, green-olive, white, pink, wine, dark-purple and orangish [35] (Figure 4). Among the most recurrent rupestrian paintings, there are 106 representations of spear throwers. Some rupestrian engravings are also observed. Recently, ceramic fragments, red and yellow ochres, and some lithic artifacts were found on the surface of the sheltered soil [32].

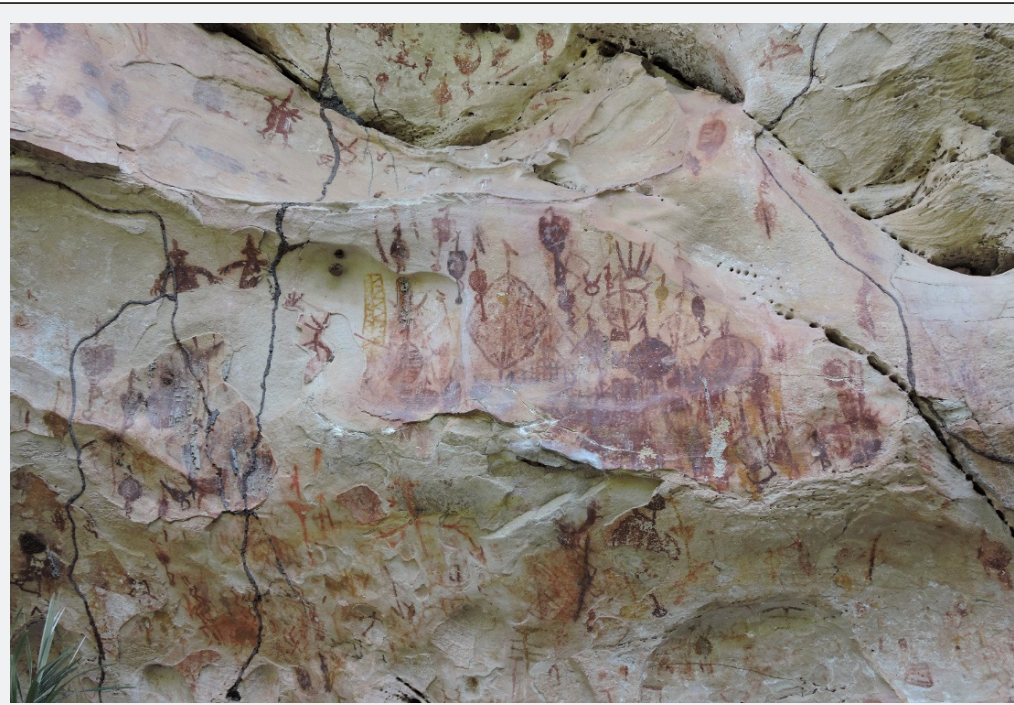

Figure 4: Details of the rupestrian paintings from the Pedra do Atlas.

Following the same research strategy proposed for the Pedra do Cantagalo I site, samples containing thin layers of paint from rupestrian paintings of different colors, as well as red and yellow Cadoz Velho I ochres, and saline efflorescences samples collected of the Pedra do Atlas site, were also investigated by several archaeometric techniques [30,32,36].

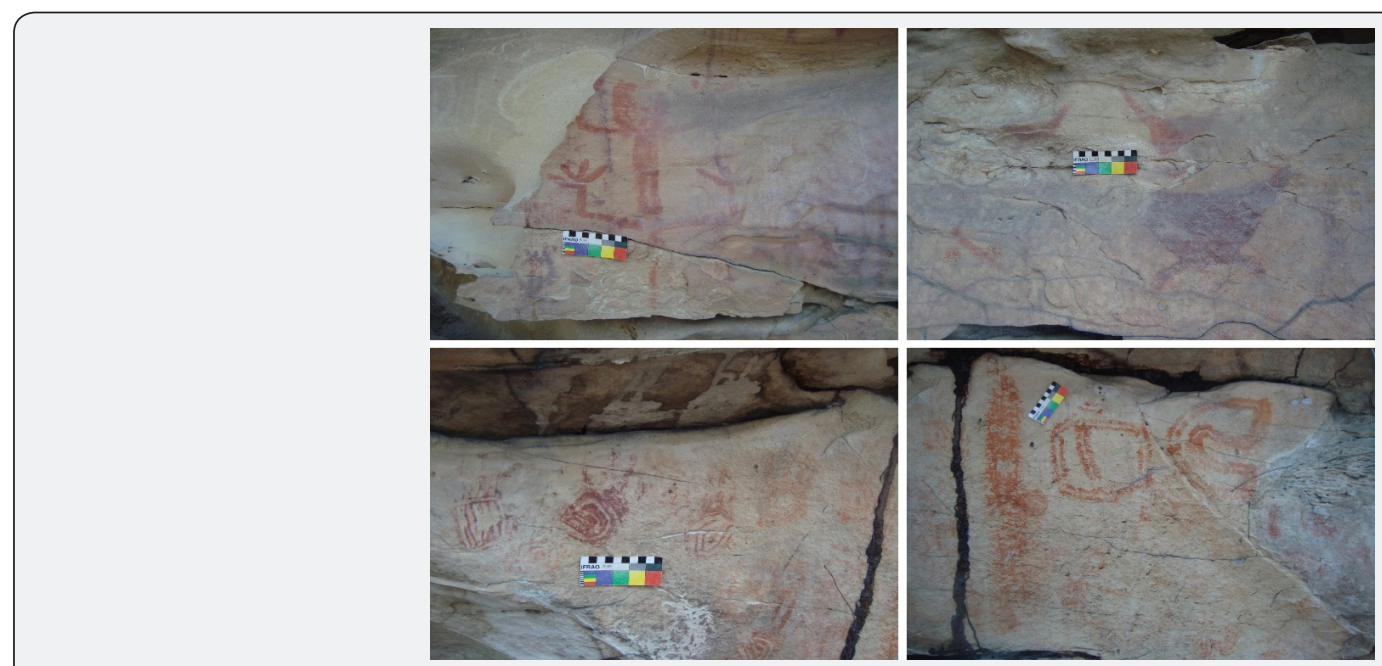

Figure 5: Details of the rupestrian paintings from the Cadoz Velho I. 


\section{Global Journal of Archaeology \& Anthropology}

The Cadoz Velho I archaeological site is a sandstone shelter located in the Cadoz Velho village, rural area of the municipality of Piripiri, containing 214 rupestrian paintings that consists of abstract figures, human handprints, zoomorphic and phytomorphic motifs, painted predominantly in different tonalities of red, but also in orange [37] (Figure 5).

\section{Fazendinha I}

The archaeological site known as Fazendinha I is a sandstone shelter with prehistoric inscriptions located in the rural area of the municipality of Piripiri [38]. The rocky shelter contains an exceptional collection of 141 rupestrian paintings and 65 rupestrian engravings. The rupestrian paintings consist of abstract figures, spear throwers, human handprints, zoomorphs (lizards), anthropomorphs and phytomorphs, painted predominantly in different tonalities of red, but also in black, orangish, wine, darkpurple, and orangish-brown (Figure 6). The rupestrian engravings (made by pecking; some finished by abrading) represent mainly cupules, but also abstract figures and a lizard (the only engraved animal known in all prehistoric sites of the archaeological region from Piripiri) [38]. Most of the engravings were also painted. Besides the high density of rupestrian inscriptions, there are overlaps and recurrences between the painted and engraved motifs.
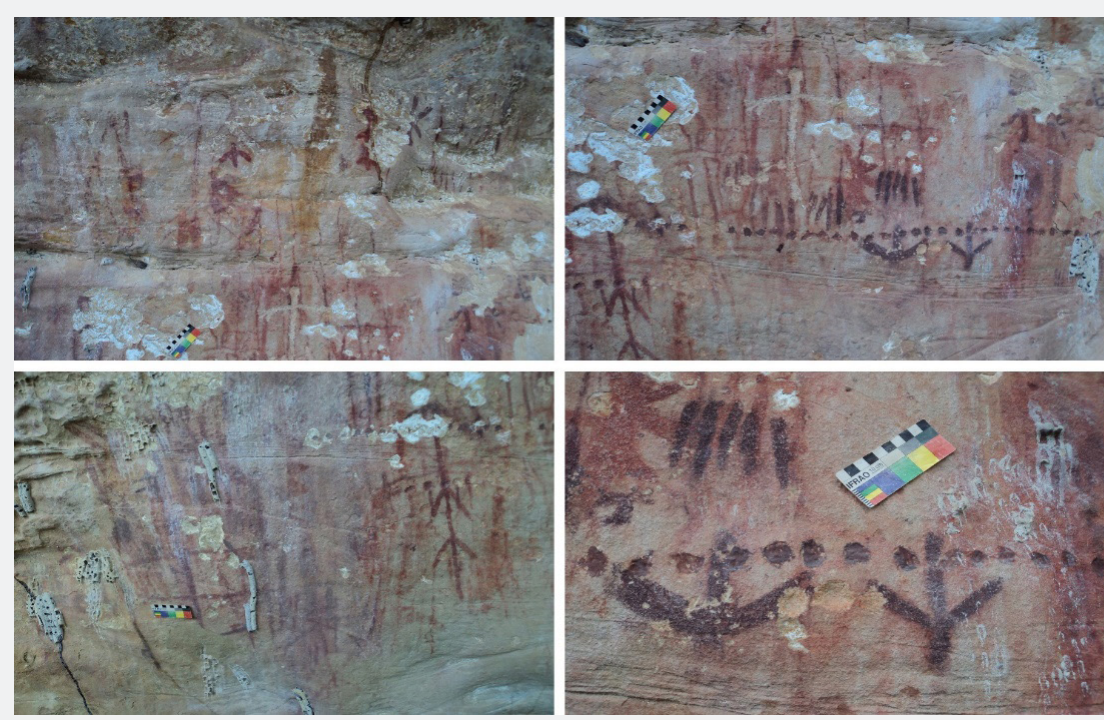

Figure 6: Details of the rupestrian paintings and engravings from the Fazendinha I.

\section{Caminho da Caiçara I}
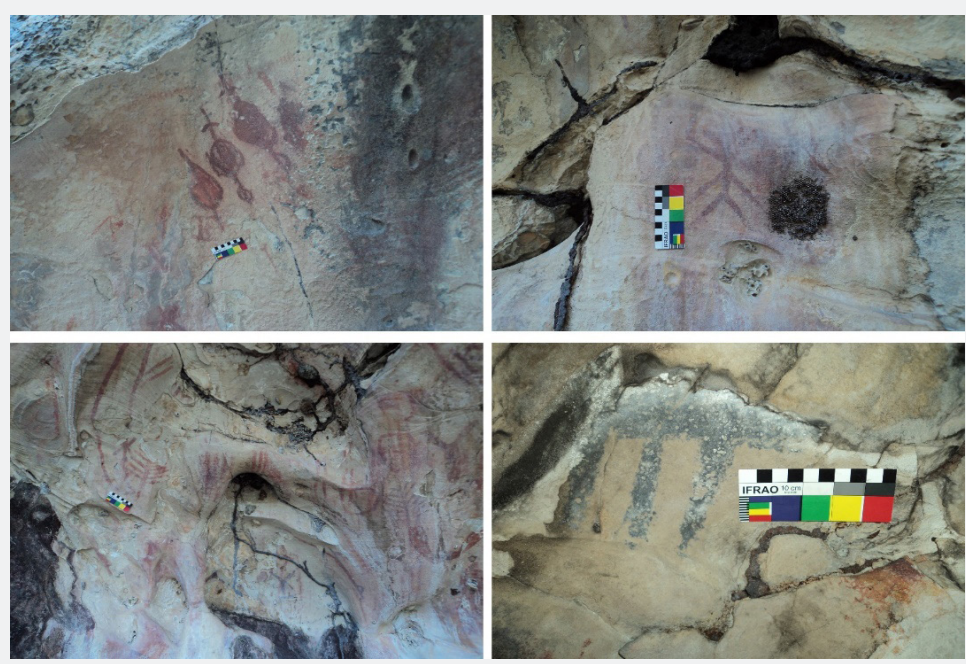

Figure 7: Details of the rupestrian paintings from the Caminho da Caiçara I.

The Caminho da Caiçara I archaeological site is in the Cadoz Velho village, rural area of the municipality of Piripiri. The sandstone walls of this prehistoric shelter are decorated with 205 rupestrian paintings representing abstract figures, spear throwers, phytomorphs and anthropomorphs, painted predominantly in different tones of red, but also in black, yellow, brown, wine and orange [39] (Figure 7). In addition to a high density of rupestrian inscriptions, there are overlaps and recurrences of painted motifs, such as spear throwers, concentric circles, sequences of sticks, agglomerates of fingerings and phytomorphs. The rupestrian engravings include cupules. 


\section{Global Journal of Archaeology \& Anthropology}

\section{Pedra Ferrada}

The Pedra Ferrada is a sandstone complex located in the Oiticica village, rural area of the municipality of Piripiri, containing
37 rupestrian paintings represent abstract figures and human handprints in different hues of red, dark-purple and orangish [40] (Figure 8).
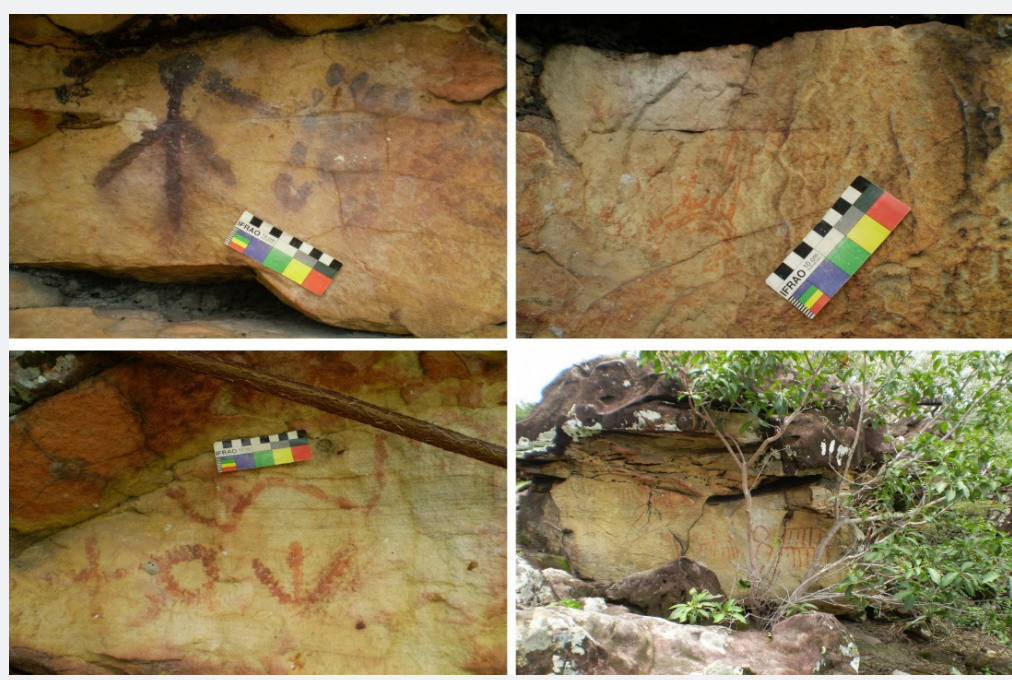

Figure 8: Details of the rupestrian paintings from the sandstone complex known as Pedra Ferrada.

\section{Pedra do Dicionário}
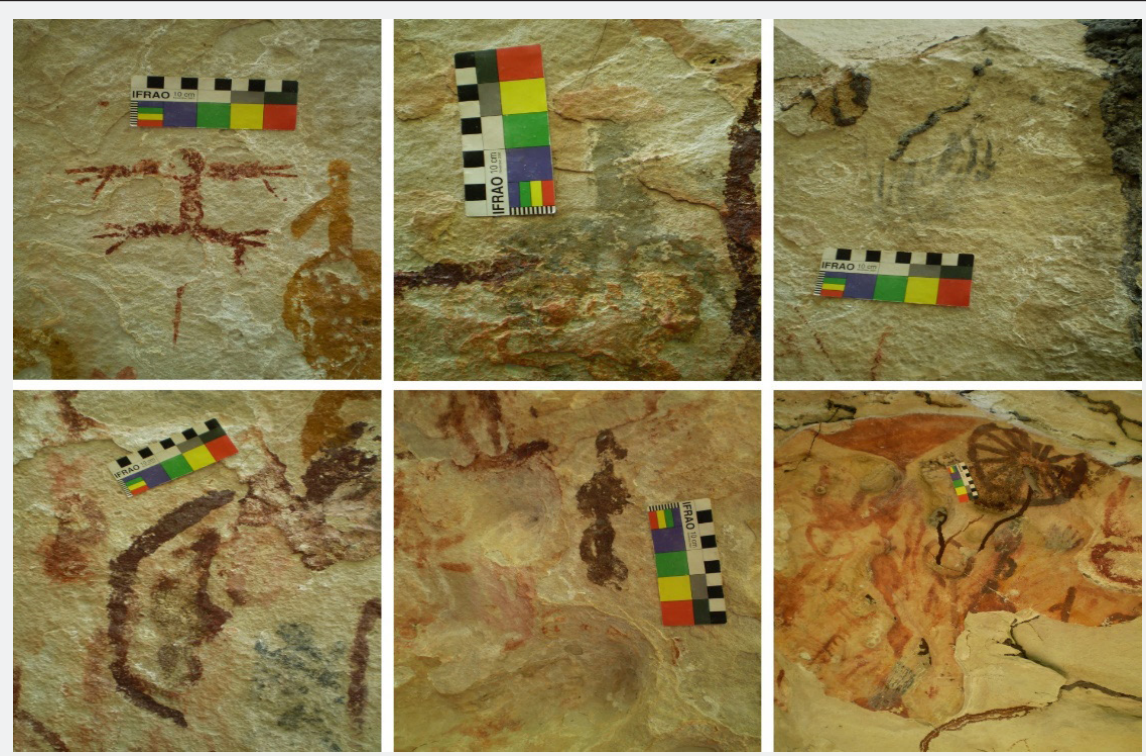

Figure 9: Details of the rupestrian paintings from the Pedra do Dicionário.

The Pedra do Dicionário is a rocky shelter located in the Buriti dos Cavalos village, rural area of the municipality of Piripiri. The sandstone walls of this archaeological site are decorated with 356 rupestrian paintings and a few rupestrian engravings in the shape of cupules; the paintings are representations of abstract figures, spear throwers, human handprints and zoomorphs, and were done predominantly in various shades of red, also existing inscriptions in yellow, wine, pink, black and orangish, highlighting a figure on the greenish-gray color, by its rarity [41] (Figure 9). Besides the polychromy, there are overlaps and recurrences of the figures represented, among which stand out 53 spear throwers and 11 human handprints.
Samples containing thin layers of paint from rupestrian paintings of different colors, as well as saline efflorescences samples collected of the Pedra do Dicionário site, were investigated by several archaeometric techniques [24].

\section{Pedra da Biblioteca}

The Pedra da Biblioteca is a sandstone shelter also located in the Buriti dos Cavalos village, rural area of the municipality of Piripiri [42]. This archaeological site is decorated with 90 rupestrian paintings, representing mainly abstract figures and spear throwers, in the gray, wine and orangish colors, and predominantly in different tonalities of red (Figure 10). Besides the prehistoric paintings, there are a few rupestrian engravings. 


\section{Global Journal of Archaeology \& Anthropology}
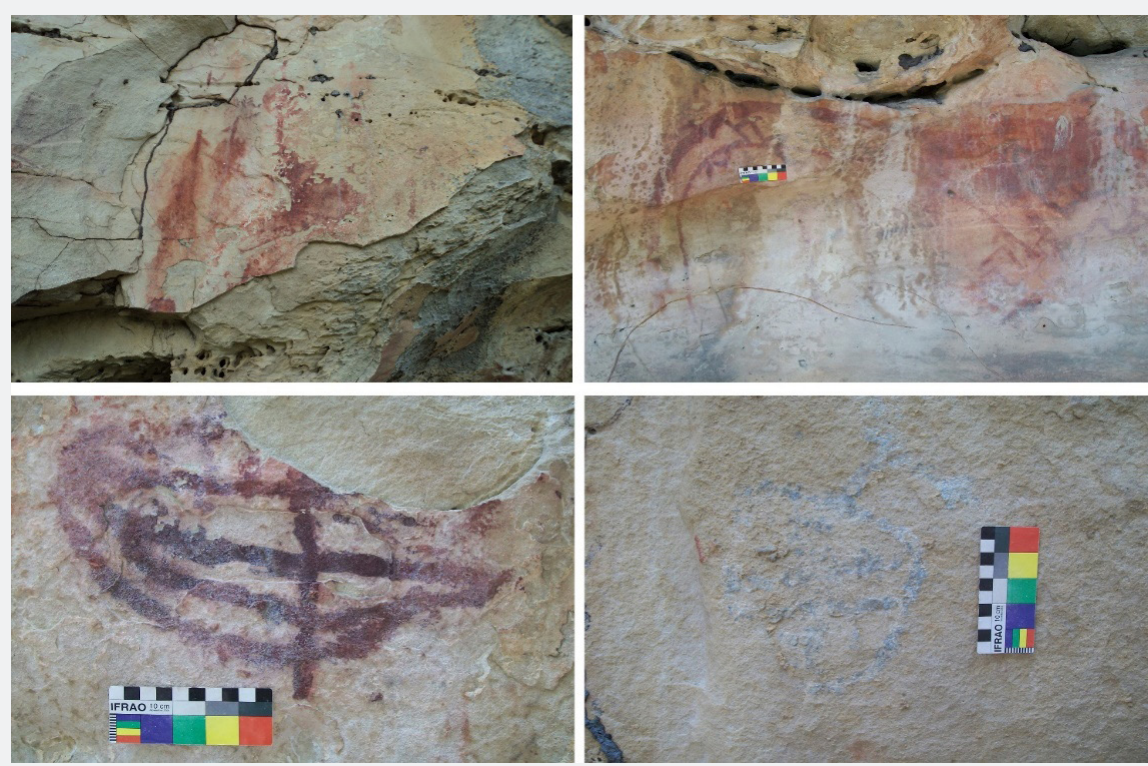

Figure 10: Details of the rupestrian paintings from the Pedra da Biblioteca

Conservation Problems from the Archaeological Sites from Piripiri

The causes of degradation of the archaeological sites from Piripiri are mainly of natural origin, due to the fragile constitution of the rocky support: the sandstone shelters are in advanced state of degradation, literally undergoing decomposition [13,35,37-42]. The state of conservation of rupestrian paintings and engravings is of concern: the prehistoric inscriptions suffer from the action of infiltrations and run-off of water, the resulting moisture encourages the formation of a variety of lichens, mosses and the growth of other microorganisms [13,35,37-42]. Suffer also by the thick layers of saline efflorescences, wind erosion, animal-dejects and insects (such as termites and wasp nests, and hives of bees), besides the mechanical, chemical and biological degradation caused by plants attaching to rocky supports.

Unfortunately, human interventions are also responsible for serious conservation problems in these archaeological sites, predominantly by deposition garbage on unguided visits, graffiti (including about the rupestrian paintings and engravings), removal of native vegetation surrounding of rocky shelters, and fires [13,35,37,40-42]. Domestic animals are also often found in the sandstone shelters, leaving thick layers of dejects on the archaeological sediments.

\section{General Considerations and Future Challenges}

The southeastern from Piauí is known internationally for presenting, in the area of the Serra da Capivara National Park and its surroundings, the largest concentration of archaeological sites containing rupestrian art, per square meter, of the world. However, the rest of Piauí, likewise, presents dotted with traces related to the presence of prehistoric human groups, especially, prehistoric cave paintings, found in shelters and rocky blocks from north to south.
In this article, it was shown that the municipality of Piripiri, in the north of Piauí, has an important concentration of sandstone shelters decorated with paintings and rock engravings. Despite of relatively smaller amount of data about such prehistoric sites, of the several difficulties, mainly to carry out field activities, the data already obtained provide stimulating evidences with detailed information about the graphic characteristics of this rich archaeological heritage. The preliminary survey of eight archaeological sites showed that these sandstone shelters present high density of rupestrian paintings made with different colors. Besides the polychromy, the prehistoric inscriptions exhibit frequent overlaps and recurrences of the motifs represented in the rocky supports, mainly spear throwers and human handprints. The graphic features these paintings are essentially different from those found in the Serra da Capivara National Park, Southeastern of Piauí.

The occurrence of serious conservation problems points to the need for urgent interventions, since some of them, such as termites, are moving forward quickly on the rupestrian paintings, besides of removal of graffiti, for example. Is need the elaboration of a pre-diagnosis, with proposals for action to remove or control the most degrading agents.

\section{Acknowledgment}

Work supported by the National Council for Scientific and Technological Development (CNPq; grants \# 487148/2013-4 and \# 313431/2017-5). The author thank Andrews Araújo Rodrigues, Cecília Aparecida Lima, Elnathan Nícolas Lima da Costa, Heralda Kelis Sousa Bezerra da Silva, Pablo Roggers Amaral Rodrigues, Petherson Farias de Oliveira, Ruan Nery Gonçalves, Victor Hugo Gomes Tostes and Yana Raquel Viana Alves, students at UFPI, for their help on the field and laboratory works; and particularly grateful to Dr. José Domingos Ardisson (Research Center for the Development of Nuclear Technology-CDTN, Belo Horizonte, Minas 


\section{Global Journal of Archaeology \& Anthropology}

Gerais, Brazil), for their help with the Mössbauer measurements at low temperatures, and to Dr. José Domingos Fabris (Universidade Federal de Minas Gerais - UFMG, Belo Horizonte, Minas Gerais, Brazil), for his unrestricted support and constant help for the carrying out the archaeometric measurements.

\section{References}

1. Martin G (2008) Pré-história do Nordeste do Brasil, Editora Universitária da UFPE, Recife.

2. Etchevarne C (2007) Escrito na pedra: cor, forma e movimento nos grafismos rupestres da Bahia/Written on stone: color, form and movement in the rock graphics of Bahia. Rio de Janeiro, Odebrecht, Brazil.

3. Kinoshita A, Figueiredo AMG, Felice GD, Lage MCSM, Guidon N, et al. (2008) Electron spin resonance dating of human teeth from Toca da Santa shelter of São Raimundo Nonato, Piauí, Brazil. Nucl Instr and Meth in Phys Res B 266: 635-639.

4. Guidon N, Pessis AM, Martin G (2009) Pesquisas arqueológicas na região do Parque Nacional Serra da Capivara e seu entorno (Piauí, 1998-2008). Fumdhamentos 8: 1-61.

5. Pessis AM (2003) Imagens da pré-história: Parque Nacional Serra da Capivara. FUMDHAM/Petrobrás, São Paulo, Brazil.

6. Pessis AM, Guidon N (2009) Dating rock art paintings in Serra de Capivara National Park: combined archaeometric techniques. Adoranten 1: 49-59.

7. Watanabe S, Ayta WEF, Hamaguchi H, Guidon N, La Salvia ES, et al. (2003) Some evidence of a date of first humans to arrive in Brazil. J Archaeol Sci 30: 351-354

8. Guidon N, Guérin C, Faure M, Felice GD, Buco C, et al. (2009) Toca das Moendas, Piauí-Brasil: primeiros resultados das escavações arqueológicas. Fumdhamentos 8: 70-85.

9. Guidon N, Pessis AM, Parenti F, Guérin C, et al. (2002) Pedra Furada, Brazil: paleoindians, paintings, and paradoxes. Athena Rev 3(2): 42-52.

10. Cavalcante LCD, Fabris JD, Lage MCSM (2018) Archaeometric analysis of prehistoric rupestrian paintings from the Toca do Estevo III site, Piauí, Brazil J Archaeol Sci Rep 18: 798-803.

11. Cavalcante LCD (2015) Pinturas rupestres da região arqueológica de Piripiri, Piauí, Brasil. Arqueol Iberoam 26: 6-12.

12. Cavalcante LCD (2016) Sítios arqueológicos do vale do Buriti dos Cavalos: uma breve revisão. Arqueol Iberoam 30: 16-22.

13. Cavalcante LCD, Rodrigues AA (2010) Arte rupestre e problemas de conservação da Pedra do Cantagalo I. Int J S Am Archaeol 7: 15-21.

14. Cavalcante LCD, Rodrigues AA, Costa ENL, Silva HKSB, Rodrigues PRA, et al. (2014) Pedra do Cantagalo I: uma síntese das pesquisas arqueológicas. Arqueol Iberoam 23: 45-60.

15. Oliveira PF (2013) Análise tipológica preliminar da cultura material do sítio Pedra do Cantagalo I e seu entorno, Teresina, Universidade Federal do Piauí, BSc Thesis, Brazil.

16. Cavalcante LCD, da Silva HKSB, Fabris JD, Ardisson JD (2017) Red and yellow ochres from the archaeological site Pedra do Cantagalo I, in Piripiri, Piauí, Brazil. Hyperfine Interact 238(1): 1-7.

17. Cavalcante LCD (2018) Arqueometria e o sítio arqueológico Pedra do Cantagalo I: uma estratégia de investigação como modelo para a América do Sul. Cadernos do Lepaarq 15(30): 315-326.

18. Cavalcante LCD (2012) Caracterização arqueométrica de pinturas rupestres pré-históricas, pigmentos minerais naturais e eflorescências salinas de sítios arqueológicos. Belo Horizonte, Universidade Federal de Minas Gerais, PhD Thesis, Brazil.
19. Costa ENL (2015) Análise de sedimentos do sítio Pedra do Cantagalo I: uma busca por indicadores arqueométricos de atividade humana préhistórica, Teresina, Universidade Federal do Piauí, BSc Thesis.

20. Silva HKSB (2015) Análise de pinturas rupestres da Pedra do Cantagalo I com espectrômetro Mössbauer miniaturizado MIMOS II, Teresina, Universidade Federal do Piauí, BSc Thesis, Brazil.

21. Silva HKSB (2018) Análise químico-mineralógica de ocres e a busca por correlações arqueológicas com os pigmentos de pinturas rupestres do sítio Pedra do Cantagalo I, Teresina, Universidade Federal do Piauí, MSc Thesis, Brazil.

22. Cavalcante LCD, Lage MCSM, Pereira MC, Fabris JD (2008) Estudo químico e espectroscópico dos pigmentos pré-históricos do sítio de arte rupestre Arco do Covão, Piauí, Brasil. Int J S Am Archaeol 3: 59-66.

23. Cavalcante LCD, Luz MF, Guidon N, Fabris JD, Ardisson JD (2011) Ochres from rituals of prehistoric human funerals at the Toca do Enoque site, Piauí, Brazil. Hyperfine Interact 203(1-3): 39-45.

24. Cavalcante LCD, Gonçalves RN, Fabris JD (2013) Análise química e mineralógica de pinturas rupestres da Pedra do Dicionário, Piripiri, Piauí, Brasil. In: Albuquerque ML, Borges SEN (Eds.), Identidades e diversidade cultural: patrimônio arqueológico e antropológico do Piauí-Brasil e do Alto Ribatejo-Portugal, FUNDAC-CEIPHAR-ITM, Teresina/Mação, pp. 34-52.

25. Cavalcante LCD, Magalhães SMC, Silva ELS, Silva HKSB (2016) Análise arqueométrica de pinturas rupestres pré-históricas do sítio Tamboril, Barras, Piauí, Brasil. Arqueol Iberoam 29: 44-49.

26. Cavalcante LCD, Fabris JD, Araújo IL (2015) Estudo arqueométrico de cerâmicas arqueológicas do sítio Lagoa do Portinho I. Clio Arqueológica 30(2): 190-242.

27. Souza MCP (2009) Caracterização químico-mineralógica de pigmentos de arte rupestre pré-histórica dos sítios Pedra Furada dos Picos e Letreiro do Ninho do Urubu, Teresina, Universidade Federal do Piauí, MSc Thesis, Brazil.

28. Santos LM (2010) Análise químico-mineralógica de pinturas rupestres do sítio Salão dos Índios (Piauí-Brasil), Teresina, Universidade Federal do Piauí, MSc Thesis, Brazil.

29. Alves TL, Brito MAML, Lage MCSM, Cavalcante LCD, Fabris JD (2011) Pigmentos de pinturas rupestres pré-históricas do sítio Letreiro do Quinto, Pedro II, Piauí, Brasil. Quim Nova 34(2): 181-185.

30. Lima CA (2014) Análise arqueométrica de pinturas rupestres e eflorescências salinas do sítio Pedra do Atlas, Piripiri, Piauí, Teresina, Universidade Federal do Piauí, BSc Thesis, Brazil.

31. Lage MCSM, Cavalcante LCD, Klingelhöfer G, Fabris JD (2016) Insitu ${ }^{57} \mathrm{Fe}$ Mössbauer characterization of iron oxides in pigments of a rupestrian painting from the Serra da Capivara National Park, in Brazil, with the backscattering Mössbauer spectrometer MIMOS II. Hyperfine Interact 237(1): 1-7.

32. Cavalcante LCD, Tostes VHG (2017) Espécies ferruginosas em pigmentos minerais do sítio arqueológico Pedra do Atlas. Arqueol Iberoam 36: 48-53.

33. Santos LM, Oliveira FM, Farias Filho BB, Fontes LM, Lage MCSM, et al. (2018) Chemical and mineralogical characteristics of the pigments of archaeological rupestrian paintings from the Salão dos Índios site, in Piauí, Brazil. J Archaeol Sci Rep 18: 792-797.

34. Silva HKSB, Cavalcante LCD, Fabris JD (2017) Características químicomineralógicas de fontes de pigmentos minerais em depósitos naturais do entorno do sítio arqueológico Pedra do Cantagalo I, em Piripiri, Piauí, Brasil. Arqueol Iberoam 36: 36-42.

35. Cavalcante LCD, Rodrigues PRA (2009) Análise dos registros rupestres e levantamento dos problemas de conservação do sítio Pedra do Atlas, Piripiri, Piauí. Clio Arqueológica 24(2): 154-173. 
36. Cavalcante LCD (2018) Caracterização químico-mineralógica de eflorescências salinas do sítio arqueológico Pedra do Atlas. Arqueol Iberoam 38: 55-60.

37. Cavalcante LCD, Rodrigues AA (2012) Pinturas rupestres do sítio Cadoz Velho I, Piripiri, Piauí. Rupestreweb p. 1-18.

38. Cavalcante LCD, Rodrigues AA (2016) Fazendinha I: descoberta de um novo sítio pré-histórico e descrição preliminar de suas inscrições rupestres e problemas de conservação. Arqueol Iberoam 30: 44-50.

39. Cavalcante LCD, Rodrigues AA (2016) Arte rupestre e problemas de conservação do sítio arqueológico Caminho da Caiçara I. Arqueol Iberoam 31: 20-26.
40. Cavalcante LCD, Ferreira ALN, Castro M, Sousa NG (2013) Arte rupestre no quintal: o caso da Pedra Ferrada e o desafio da preservação patrimonial. Rupestreweb p.1-10.

41. Cavalcante LCD, Rodrigues PRA (2012) Pedra do Dicionário: registros rupestres e propostas de intervenção de conservação. Clio Arqueológica 27(2): 241-264.

42. Cavalcante LCD, Rodrigues PRA (2016) Pedra da Biblioteca: um sítio arqueológico com inscrições rupestres pré-históricas. Mneme 17(39): 289-310.

\section{Your next submission with Juniper Publishers will reach you the below assets}

- Quality Editorial service

- Swift Peer Review

- Reprints availability

- E-prints Service

- Manuscript Podcast for convenient understanding

- Global attainment for your research

- Manuscript accessibility in different formats

( Pdf, E-pub, Full Text, Audio)

- Unceasing customer service

Track the below URL for one-step submission https://juniperpublishers.com/online-submission.php 